ROCZNIK POLSKO-NIEMIECKI 2018, nr 26

ISSN 1230-4360

DOI: $10.35757 /$ RPN.2018.26.14

\title{
Ewelina Wanat
}

Uniwersytet Techniczny w Chemnitz

\section{Między Nową Marchią a Wielkopolską. Jak „skonstruowano” nowy region w powojennej Polsce}

Kerstin Hinrichsen, Die Erfindung der Ziemia Lubuska. Konstruktion und Aneignung einer polnischen Region 1945-1975, Wydawnictwo Vandenhoeck \& Ruprecht, Göttingen 2017 , ss. 354.

Autorką recenzowanej pracy jest Kerstin Hinrichsen kulturoznawczyni i historyczka zajmująca się dziejami Europy Środkowo-Wschodniej. Naukowo związana jest z Uniwersytetem we Frankfurcie nad Odrą. Jej zainteresowania badawcze koncentrują się m.in. na analizie stosunków polsko-niemieckich, polityce pamięci oraz tematyce migracji.

Obroniona w 2015 roku na Uniwersytecie w Siegen, a wydana nakładem wydawnictwa V\&R w Getyndze w 2017 roku dysertacja koncentruje się wokół zagadnienia powstawania regionów (region building) na przykładzie Ziemi Lubuskiej. Jak wyjaśnia autorka, „wynalezienie” Ziemi Lubuskiej miało swoje polityczne podłoże. Służyło ono według Hinrichsen m.in. legitymizacji władzy polskiej na tym obszarze oraz pełniło rolę wspomagającą w stworzeniu więzi osiedlonej tam ludności polskiej z zamieszkiwanym przez nią regionem. Autorka wymienia dwa czynniki umożliwiające stworzenie owego konstruktu Ziemi Lubuskiej. Jako pierwszy czynnik został wymieniony brak granic historycznych regionu. Drugim czynnikiem jest brak regionalnych instytucji oraz świadomości regionalnej i identyfikacji mieszkańców z regionem. Hinrichsen zwraca uwagę na heterogenność tworzącego się społeczeństwa po 1945 roku, ale nie porusza bliżej kwestii tożsamościowych przybyłych grup osadników, a wszystkich mieszkańców określa mianem Lubuszan.

Zakres czasowy omawianej pracy obejmuje lata 1945-1975. Pierwsza cezura odnosi się do zakończenia II wojny światowej i związanych z nią zmian geopolitycznych w Eu- 
ropie. Natomiast druga data graniczna wyznacza reformę administracyjną i w jej konsekwencji podział Ziemi Lubuskiej. Ramy terytorialne obszaru badawczego zostały zawężone do historycznych ziem Nowej Marchii, Śląska, Łużyc, Wielkopolski i Pomorza, których części stały się przedmiotem konstrukcji nowego regionu - Ziemi Lubuskiej.

Autorka recenzowanej pracy sformułowała następujące pytania badawcze: w jakim celu i za pomoca jakich środków konstruowano region? Co motywowało lokalnych animatorów i kim oni byli oraz w jaki sposób tworzono wiedzę o regionie i jak ją rozpowszechniano.

Hinrichsen nie uwzględniła w swoich badaniach roli, jaką odgrywać mogły w procesie konstrukcji regionu instytucje kościelne, oświata oraz literatura i sztuka, o czym informuje czytelnika we wstępie.

W swojej pracy Hinrichsen posłużyła się szeroką gamą źródeł historycznych. Wykorzystała źródła archiwalne, znajdujące się w zasobach archiwów państwowych w: Poznaniu, Zielonej Górze, Gorzowie Wielkopolskim, Archiwum Akt Nowych w Warszawie oraz Archiwum Polskiej Akademii Nauk. Bazę źródłową uzupełniła regionalną prasą, z której należy wymienić m.in. „Rocznik Lubuski”, „Przegląd Lubuski”, monografie i studia regionalne prowadzone na Uniwersytecie w Zielonej Górze, podręczniki szkolne, leksykony, a nawet lokalne bajki i legendy. Do dalszych źródeł, z których korzystała Hinrichsen, należą zasoby regionalnych lubuskich jednostek muzealnych i bibliotek.

Hinrichsen podzieliła swoją monografię na sześć rozdziałów uzupełnionych podrozdziałami, zachowując porządek chronologiczny. W pierwszym rozdziale autorka monografii przybliża czytelnikowi historię badanego regionu. Hinrichsen przedstawia wywód historyczny, tworzony przez ówczesną politykę w celu konstrukcji Ziemi Lubuskiej. Ponadto wzmiankuje o wymianie ludności, która miała miejsce na tym obszarze po zakończeniu działań wojennych w 1945 roku. Uwzględnia przy tym przymusowe wysiedlenie Niemców oraz równolegle odbywające się osadnictwo polskiej ludności. W jednym z podrozdziałów omawia mit "Ziemi Odzyskanych" i przybliża re p o lo n i zację regionu. Następnie zaś wyjaśnia, „czym jest Ziemia Lubuska”.

Drugi rozdział poświęcony został przedstawieniu historii regionu i jej popularyzacji w społeczeństwie. Autorka przywołuje w tym miejscu jako materiał źródłowy m.in. literaturę naukową, w tym książki o tematyce historycznej, ponadto ówczesne przewodniki turystyczne, kinematografię, a nawet bajki. Przywołuje przykłady ówczesnej retoryki politycznej mające udowadniać prapolskość regionu. Jako przykład podaje Towarzystwo Polskich Rzemieślników w Zielonej Górze czy też wykorzystanie wizerunku lokalnego malarza Taddeo Polacco. Hinrichsen przedstawia rolę tworzenia nowych tradycji, które miały na celu utrwalenie w świadomości mieszkańców regionu ich przynależności do danego obszaru. Analizuje aspekty związane z popularyzacją wizerunku Zielonej Góry jako centrum polskiego winiarstwa. Jej uwagę przyciaga również sprawa miejskiego hejnału i herbu.

Kolejny rozdział poświęcony został kulturalnemu regionalizmowi na Ziemi Lubuskiej i podzielony został na dwa czasookresy. Pierwszy obejmuje lata od 1945 do 1956, a drugi omawia okres po roku 1956. Hinrichsen analizuje w tym miejscu powstanie i rozwój lokalnego życia kulturowego. Omawia amatorski ruch teatralny, działalność 
świetlicowa, zakładowe grupy animatorów kultury, ale przede wszystkim koncentruje swoją uwagę na lokalnych muzeach, teatrach i kinach. W centrum jej uwagi stoi również Lubuskie Towarzystwo Kultury i rola, jaką odgrywało w życiu kulturowym regionu.

Rozdział czwarty koncentruje się na badaniach regionalnych prowadzonych $\mathrm{w}$ omawianym regionie, jak i w instytucjach spoza regionu, których przedmiotem badań jest Ziemia Lubuska. W jednym z podrozdziałów Hinrichsen prezentuje rolę Instytutu Zachodniego w Poznaniu w badaniach nad regionem lubuskim. Ponadto nawiązuje do koncepcji twórców polskiej myśli zachodniej. Prezentuje również sylwetki pracowników naukowych związanych z Instytutem i ich wkład w badania nad Ziemią Lubuską. Następnie autorka przedstawia lubuską drogę do bycia ośrodkiem badań regionalnych. Prezentuje portrety lokalnych regionalistów oraz ich wkład w stan badań i upowszechnianie wiedzy o badanym regionie.

W piątym rozdziale Hinrichsen przedstawia Ziemię Lubuska, widzianą oczami turystów. W tym miejscu autorka przywołuje obraz regionu przedstawiany w przewodnikach turystycznych. Omawiając działalność Towarzystwa Turystyczno- Krajoznawczego, Hinrichsen koncentruje swoją uwagę na regionalnych oddziałach omawianej instytucji oraz ich popularności. Przedstawia zarówno stan infrastruktury, jak i bazy turystycznej w regionie.

Ostatni rozdział pracy wychodzi poza ramy czasowe omawianej monografii i stanowi rodzaj dygresji. Omówiony został tutaj okres w historii Ziemi Lubuskiej po 1975 roku, w szczególności reformy admiracyjne z lat 1975 i 1998 do powstania województwa lubuskiego.

Recenzowana monografia udowadnia, iż powstanie Ziemi Lubuskiej jako regionu jest konstruktem, który swoje źródła ma w powojennej polityce i ideologii. Do zalet recenzowanej pracy należy niewątpliwie wykorzystana baza źródłowa oraz dobrze dobrane przykłady realizacji celów politycznych $\mathrm{w}$ regionie. $\mathrm{W}$ monografii pojawiają się drobne literówki, głównie w polskich wyrazach (np. por. s.18, 25, 47, 238, 240), nie utrudniają one jednak zrozumienia treści, ale wpływają na aspekt estetyczny pracy. Książkę można byłoby wzbogacić o badania statystyczne, które prezentowałby stosunek mieszkańców do regionu, ich identyfikacje z Ziemią Lubuską lub więcej uwagi poświęcić powojennej propagandzie. Omawiając wysiedlenie Niemców, Hinrichsen nie uwzględnia niemieckojęzycznej ludności serbołużyckiej, która w okresie powojennym zamieszkiwała teren na wschód od Odry. W tym miejscu należy wyjaśnić, iż Serbołużyczanie nie posługiwali się w życiu publicznym - a rzadko w życiu prywatnym - własnym językiem dolnołużyckim. Poprzez używanie języka niemieckiego często postrzegani byli jako Niemcy. Autorka datuje w podrozdziale ostatniego rozdziału reformę administracyjną na rok 1998, co jest błędne. Wprawdzie ustawa reformująca polską administrację została podpisana przez prezydenta w 1998 roku, ale w życie weszła 1 stycznia 1999 roku (Dz.U. 1998, nr 96, poz. 603).

Monografia Kerstin Hinrichsen jest wartościową i ciekawą pracą wnosząca istotny wkład w literaturę przedmiotu. Jest godna polecenia wszystkim czytelnikom, którzy swoje zainteresowania skupiają na historii kulturowej oraz stosunkach polsko-niemieckich. 